\title{
Central catheter dressing in a simulator: the effects of tutor's assistance or self-learning tutorial ${ }^{1}$
}

\author{
Milene Thaís Marmol \\ Fernanda Titareli Merizio Martins Braga ${ }^{3}$ \\ Livia Maria Garbin ${ }^{4}$ \\ Lucimara Moreli ${ }^{5}$ \\ Claudia Benedita dos Santos ${ }^{6}$ \\ Emilia Campos de Carvalho ${ }^{7}$
}

\begin{abstract}
Aims: to compare the performance of undergraduate students concerning semi-implanted central venous catheter dressing in a simulator, with the assistance of a tutor or of a self-learning tutorial. Method: Randomized controlled trial. The sample consisted of 35 undergraduate nursing students, who were divided into two groups after attending an open dialogue presentation class and watching a video. One group undertook the procedure practice with a tutor and the other with the assistance of a self-learning tutorial. Results: in relation to cognitive knowledge, the two groups had lower performance in the pre-test than in the post-test. The group that received assistance from a tutor performed better in the practical assessment. Conclusion: the simulation undertaken with the assistance of a tutor showed to be the most effective learning strategy when compared to the simulation using a self-learning tutorial. Advances in nursing simulation technology are of upmost importance and the role of the tutor in the learning process should be highlighted, taking into consideration the role this professional plays in knowledge acquisition and in the development of critical-reflexive thoughts and attitudes. (ClinicalTrials.gov Identifier: NCT 01614314).
\end{abstract}

Descriptors: Preceptorship; Simulation; Nursing; Catheters.

\footnotetext{
${ }^{1}$ Supported by Conselho Nacional de Desenvolvimento Científico e Tecnológico (CNPq), process \# 474499/2010-3.

${ }^{2}$ RN.

${ }^{3}$ RN, PhD, Escola de Enfermagem de Ribeirão Preto, Universidade de São Paulo, WHO Collaborating Centre for Nursing Research Development, Brazil.

${ }^{4}$ RN and Doctoral Student, Escola de Enfermagem de Ribeirão Preto, Universidade de São Paulo, WHO Collaborating Centre for Nursing Research Development, Brazil.

${ }^{5}$ Master's student, Escola de Enfermagem de Ribeirão Preto, Universidade de São Paulo, WHO Collaborating Centre for Nursing Research Development, Brazil.

${ }^{6}$ PhD, Associate Professor, Escola de Enfermagem de Ribeirão Preto, Universidade de São Paulo, WHO Collaborating Centre for Nursing Research Development, Brazil.

7 PhD, Full Professor, Escola de Enfermagem de Ribeirão Preto, Universidade de São Paulo, WHO Collaborating Centre for Nursing Research Development, Brazil.
}

Corresponding Author:

Emilia Campos de Carvalho

Universidade de São Paulo. Escola de Enfermagem de Ribeirão Preto

Departamento de Enfermagem Geral e Especializada

Av. dos Bandeirantes, 3900

Bairro: Monte Alegre

CEP: 14040-902, Ribeirão Preto, SP, Brasil

E-mail: ecdcava@eerp.usp.br 


\section{Curativo de cateter central em simulador: efeito da presença do tutor ou da aprendizagem autoinstrucional}

Objetivo: comparar o desempenho de graduandos na realização do curativo do cateter venoso central semi-implantado, em simulador, com o auxílio do tutor ou de um guia autoinstrucional. Método: trata-se de estudo experimental, controlado, randomizado. A amostra foi composta por 35 alunos de graduação em enfermagem, que foram alocados em dois grupos, após assistirem a um aula expositiva dialogada e a um vídeo. Um grupo realizou o treino do procedimento com o tutor e o outro com o auxílio de um guia autoinstrucional. Resultados: em relação ao conhecimento cognitivo, os dois grupos apresentaram desempenho menor no pré-teste, comparado ao pós-teste. O grupo com presença do tutor apresentou melhor desempenho na avaliação prática. Conclusão: a utilização de simulação, aliada à presença do tutor, mostrou ser uma estratégia de ensino mais efetiva do que a simulação dirigida por guia autoinstrucional. Avanços em simulação na área de enfermagem são de extrema importância e a figura do tutor merece destaque no processo de ensino-aprendizagem, tendo em vista o papel que esse profissional desempenha durante a aquisição de conhecimento e no desenvolvimento de pensamentos e atitudes críticos e reflexivos. (ClinicalTrials.gov Identifier: NCT 01614314).

Descritores: Tutoria; Simulação; Enfermagem; Cateteres.

\section{Parche de catéter central en simulador: efecto de la presencia del tutor o del aprendizaje auto-instruccional}

Objetivo: comparar el desempeño de graduandos en la realización del parche del catéter venoso central semi-implantado, en simulador, con el auxilio del tutor o de un guía auto-instruccional. Método: estudio experimental controlado hecho aleatorio. La muestra fue compuesta por 35 alumnos de Graduación en Enfermería que fueron asignados en dos grupos después de asistir a una clase expositiva dialogada y a un vídeo. Un grupo realizó el entrenamiento del procedimiento con el tutor y el otro con el auxilio de un guía auto- instruccional. Resultados: con relación al conocimiento cognoscitivo, los dos grupos presentaron desempeño menor en la preprueba comparada al pos-prueba. El grupo con presencia del tutor presentó mejor desempeño en la evaluación práctica. Conclusión: la utilización de simulación aliada a la presencia del tutor mostró ser una estrategia de enseñanza más efectiva del que la simulación dirigida por guía auto-instruccional. Avances en simulación en el área de enfermería son de extrema importancia y la figura del tutor merece destaque en el proceso enseño-aprendizaje, teniendo en vista el papel que este profesional desempeña durante la adquisición de conocimiento y en el desarrollo de pensamientos y actitudes críticos reflexivos. (ClinicalTrials.gov Identifier: NCT 01614314).

Descriptores: Tutoría; Simulación; Enfermería; Catéteres.

\section{Introduction}

Educators in the $21^{\text {st }}$ century have been using innovative strategies for theoretical-practical education, and simulation is a valued tool in the educational strategy. It permits the acquisition of knowledge, abilities and decision making, which are required for clinical practice, and it is also considered a safe practice strategy in the health care field ${ }^{(1)}$.

In Professional Nursing, the use of simulation allows the essential aspects of the real clinical field to be reproduced in a learning environment, and offers the advantage of repeatability as many times as needed, which enhances the learning process and supports students' autonomy, independence and self-confidence in relation to care practices ${ }^{(2)}$. In this context, the need to have a teacher/tutor during simulation or only a selflearning tutorial in order to gain knowledge and abilities in the nursing field is questioned.

Along the years, the professional development tutor figure has been used and valued as qualifying in the pedagogical process ${ }^{(3)}$. As for undergraduate education, 
the tutor performs the role of directing the graduation, guiding and facilitating the learning process that is focused on the student. For this, amongst the essential requirements to perform this role, in addition to clinical competence and capacity to assist with learning, tutors also need to understand professional practice ${ }^{(4)}$.

According to the creators of a proposal for a tutorial model for nursing courses, a tutorial program represents the availability of resources for students' support and it can develop a number of perspectives, according to the detected needs assessment. The program can comprise two dimensions, the educational and the caregiving, in which the educational dimension offers pedagogical support programs to students in order to help them to improve their academic performance, with the development of technical and procedural abilities as one of the aspects that are dealt with(5).

The present study was aimed at investigating the effectiveness of tutors' assistance and of self-learning tutorials as learning strategies applied to undergraduate nursing students in the performance of a certain procedure in a simulated situation.

In order to elaborate the educational content, a semi-implanted central venous catheter dressing procedure was chosen (CVC-SI). At the educational institution where this study was developed, this procedure is taught as an elective unit for undergraduate students and for students of the specialization course in oncology nursing.

The CVC-SI is a type of indwelling central venous catheter used for various purposes. These include the infusion of large amounts of liquids, simultaneously and for long periods, central venous pressure monitoring and safe infusion of hematopoietic stem cells ${ }^{(6)}$, particularly in oncology patients.

A large number of advantages are mentioned in the literature in relation to the use of this instrument ${ }^{(6)}$; however, some complications may be associated, one of which is the infection caused by the tear of patients' skins, which could ultimately cause death ${ }^{(7-8)}$.

Dressing is one of the care practices for the prevention of infection, and a variety of materials can be used(7).

Although no differences have been identified in the literature with regard to the risk of occurrence of infection concerning dressings made with polyurethane film and those made with sterile gauze and adhesive tape(6), some advantages are stated in relation to the polyurethane dressing, as follows: longer dwelling time, longer intervals to be changed, possibility to see the catheter output area constantly, higher satisfaction and comfort of the patient, reduction of costs with material and less need for the nursing staff(6-7).

Therefore, this study was aimed at comparing the performance of undergraduate nursing students in relation to the CVC-SI polyurethane dressing procedure in a simulator, following a tutor's guidance or a selflearning tutorial.

\section{Method}

This is a randomized controlled experimental study, conducted between September and December 2011, in which the training of CVC-SI polyurethane dressing procedures was investigated, supervised by a tutor, compared to the training based on a self-learning tutorial.

The study participants students from semester eight in 2011, enrolled in the Undergraduate Diploma in Nursing in a public country town university located in Sao Paulo state. The students were invited to participate in the study by way of a classroom invitation. At that point, clarifications about the research were provided. The study sample included those students who showed interest in participating, and they signed two copies of the Informed Consent Form.

The following exclusion criteria were adopted: nonexecution of all stages of the study or scoring more than $70 \%$ in the pre-test. Those students were informed about their exclusion from the study and assured that they would participate in the other stages of learning according to their own choice.

From the 75 enrolled students, 58 showed interest in participating in the study after the invitation, and 37 participated in the initial assessment. From these, two were excluded for having scored more than $70 \%$ on the cognitive knowledge part of the CVC-SI pre-test. Although excluded from data analysis, their participation in the other stages of the learning process was guaranteed. The other 21 stated they were unavailable to be present at the times allocated for the research; therefore, 35 students participated in the study.

The first step in the research was an assessment of cognitive knowledge as a pre-test. Following this, an open dialogue presentation class about CVC-SI was held and its structure was based on the literature. After the class, the students watched a video that had been prepared for this study and showed the CVC-SI dressing procedure. At the end, the same initial assessment was applied, now as a post-test. 
Afterwards, the students were randomly divided into two groups. For this purpose, the computer program Random Allocation Software, version 1.02004 was used. Group A undertook the training of the dressing procedure in a simulator with the assistance of a tutoring nurse. Students in Group B undertook training with the assistance of a self-learning tutorial that contained the steps for the execution of the procedure. In both groups, training was undertaken individually and the maximum duration established was one hour, but they could interrupt it before the end of the time limit if they felt it was enough.

At the end of the training, when students had performed the procedure, they were assessed by a member of the research team who had not served as a tutor. For this, a checklist was used for the analysis of the practical performance of the CVC-SI dressing procedure. It is important to mention that both the open dialogue presentation class followed by the educational video and the performance of the procedure in a laboratory were undertaken beyond compulsory curricular activities hours.

Two tutors participated in the study, both nurses with experience in performing the CVC-SI dressing procedure and in undergraduate education, one of them having 11 years of experience and the other 9 years.

During Group A's training, the tutor acted as a facilitator in the learning process, which was individualized for each student in accordance with the needs showed during training. Thus, appointments were made, when needed or requested by the student, addressing the preparation of material, sequence of technical execution, maintenance of aseptic principles, handling specificity and dressing fixation, as well as its removal. In relation to Group $B$, the student undertook training with the assistance of a self-learning tutorial and without any professional assistance. This guide contained a list of materials needed and detailed steps for the performance of the procedure.

Two researchers previously trained for the application of these assessments collected the data. In the pilot study undertaken with 7 participants, two researchers were responsible for the assessment, with a $100 \%$ reliability rate. For data collection, three instruments were used as follows:

- Cognitive knowledge assessment: formed by 15 affirmative sentences about CVC-SI and dressing procedure. As for the answer, the student indicated if each sentence was true or false. This instrument was used in order to evaluate cognitive knowledge about
CVC-SI at two moments, pre and post-test, considering the number of correct answers to the questions asked (scores from 0 to 15 ).

- Checklist for the analysis of practical performance of CVC-SI dressing: it was composed of 28 items to be observed during the performance of the procedure, which were considered as satisfactory or unsatisfactory, or not undertaken. For the preparation of this instrument, the following steps were taken into consideration: preparation of the environment, patient and material, antisepsis procedure, application of the polyurethane dressing and registration of the procedure. The performance of each student was analyzed according to this instrument, allocating one point for each correct item (scores from 0 to 28 ).

- Assessment of learning experience: an instrument previously developed was used( ${ }^{(9)}$ and consisted of items to assess the students' degree of acceptance of the experience.

The cognitive knowledge assessment instrument and the checklist for the analysis of practical performance of CVC-SI dressing were submitted to content and face evaluation by five nurse judges, who worked in the oncology and education field. The judges' suggestions were related to the presentation of the two instruments, and all of the suggested changes were accepted.

The study was developed in the simulation laboratories of the university where this research took place, and the environment is prepared to simulate a hospital assistance unit. The simulator used in this study was a dummy with a CVC-SI into the thorax and humanlike skin with a real feel in its external structure.

The data collected were inserted into a Microsoft Excel spreadsheet for Windows 2007. The double data entry procedure was used to validate the database. The software Statistical Package for Social Sciences (SPSS) for Windows version 16.0 was used for statistical analysis.

The average and standard deviation were used to present the score resulting from the cognitive knowledge variable and to assess the practical performance. Concerning the assessment of the learning experience, absolute frequencies and percentages were used.

The normality of the sample mean distribution was verified with the use of the Kolmogorov-Smirnov test for the following variables: cognitive knowledge and practical performance. Further, the t-test for dependent samples was used to compare the average scores before and after the open dialogue presentation class for Group A and Group B. The t-test for independent samples was used to compare the two groups' average post-test scores 
(cognitive knowledge variable) and practical performance. Statistical significance was set at $5 \%(\alpha=0.05)$.

The project was submitted to the Research Ethics Committee at the institution where the study was developed, under registration number 1217/2010, also attaching the Informed Consent Form signed by the participants.

\section{Results}

Thirty-five students participated in the study, being one man and thirty-four women. Group A (training with a tutor) included 18 students (51\%) and Group B (training with a self-learning tutorial) seventeen students (49\%). The Kolmogorov-Smirnov test results confirmed the normal distribution of the data.

In relation to the cognitive knowledge about the CVC-SI dressing, it can be noted (Table 1) that both Group A and B performed worse on the pre-test undertaken before the open dialogue presentation class and video, compared to the results obtained afterwards, with a statistically significant difference for both groups $(p<0.001)$.

Table 1 - Average of correct answers and respective standard deviations related to the theoretical questions applied twice: before and after the open dialogue presentation class, according to studied groups. Ribeirao Preto, SP, Brazil, 2011

\begin{tabular}{|c|c|c|c|c|c|}
\hline \multirow{2}{*}{ Groups } & \multicolumn{2}{|c|}{$\begin{array}{l}\text { Correct answers pre-class (open } \\
\text { dialogue presentation + video) }\end{array}$} & \multicolumn{2}{|c|}{$\begin{array}{l}\text { Correct answers post-class (open } \\
\text { dialogue presentation + video) }\end{array}$} & \multirow[t]{2}{*}{$\mathbf{p}^{*}$} \\
\hline & Average (\%) & sd & Average (\%) & sd & \\
\hline Group A ( $n=18)$ (with tutor) & 6.7 & 2.3 & 13.8 & 0.8 & $<0.001$ \\
\hline Group B ( $n=17)$ (with self-learning tutorial) & 6.7 & 2.7 & 14.0 & 1.2 & $<0.001$ \\
\hline
\end{tabular}

*t-test for independent samples

When comparing the cognitive knowledge performance in the post-test for Groups $A$ and $B$, the difference was not significant $(p=0.516)$, which showed that both groups had similar conditions to undertake practical training.

As regards the practical performance, the rate of correct answers was different between the groups.
From the 28 analyzed items, $16(57.1 \%)$ were correctly performed by $100 \%$ of Group A, while six items (21.4\%) were correctly performed by all students in Group B. It can be noted (Table 2) that all participants who trained with the assistance of a tutor obtained a higher average performance in the practical assessment, with a statistically significant difference $(p<0.001)$.

Table 2 - Distribution of mean correct answers and respective standard deviation related to practical performance. Ribeirao Preto, SP, Brazil, 2011

\begin{tabular}{lccc}
\hline & Average & sd & p $^{*}$ \\
\hline Group A ( $n=18)$ (With tutor) & 26.8 & 1.0 & $<0.001$ \\
Group B $(n=17)$ (with self-learning tutorial) & 22.5 & 2.0 & \\
\hline
\end{tabular}

*t-test for independent samples

Whilst considering the items with the highest rates of unsatisfactory performance or those that were not performed, three items which were related to the general aspects of the dressing should be highlighted: the open and correct positioning of the tweezers for the performance of the dressing, identification of the dressing at the end of the procedure and hand washing.

It is important to mention that, in all cases, the highest rates of non-performance or unsatisfactory performance occurred in Group B.

Concerning the specific aspects related to the CVC-SI dressing, the items with the highest rates of unsatisfactory performance were related to the removal and fixation of the existing dressing, antisepsis of the ostium output and disinfection of the catheter extension, application of the new transparent polyurethane film and fixation of the catheter extension. The correct removal of the transparent polyurethane film was achieved by $88.9 \%$ of Group A students and by $5.6 \%$ in Group B. The second item with the worst rate of correct answers in Group B is related to the antisepsis of the ostium output, which was correctly performed by $41.2 \%$ of the students in this group, while all the students who received tutor guidance performed this task appropriately. This 
situation was repeated during the application of the new polyurethane film, which was correctly performed by all students in Group A and by $52.9 \%$ in Group B. The disinfection of the catheter extension was also satisfactorily performed by $100 \%$ of the students guided by tutors and by $64.07 \%$ of those who used the selflearning tutorial.

As for the learning experience assessment, all students stated that the teaching strategy used was very useful and that they would certainly recommend this activity to a colleague, and they also unanimously agreed that this experience will help their professional performance.

\section{Discussion}

Most of the participants in this study were female $(97.1 \%)$ and their predominance is also shown in other studies developed with students enrolled in nursing graduation courses ${ }^{(10-11)}$, which once again proves the predominance of women in this profession.

According to the results, there was no difference between the groups in relation to the pre-test scores, which showed homogeneity in the students' initial knowledge. The same happened after the theoretical activity, when both groups presented similar results. The different scores both groups obtained on the pre and post-tests evidenced learning. This situation was also noted in a quasi-experimental study involving nursing degree students, aimed at assessing the effectiveness of an educational video about the puncture and heparin infusion procedure of the implanted catheter, when the percentage of correct answers in relation to the cognitive knowledge increased significantly (from $14.2 \%$ to $90.7 \%, p<0.05)$ after the presentation of the video(10).

The efficiency of a video combined with a presentation class could also be noted in a study involving medicine students, physicians and nurses ${ }^{(12)}$, which assessed the use of an educational video when teaching intra osseous puncture in children. When the results obtained by the intervention group, who attended a class and watched a video, were compared to the results obtained by the control group, who only attended the class, it was noted that the use of the video together with the class on the acquisition of skills related to intra osseous puncture was more efficient $(p<0.01)$ than the class only.

Students should have opportunities to develop and practice their clinical skills in a safe way and in controlled environment, in order to ensure the safety of patients ${ }^{(13)}$ and with the expectation of reducing errors during clinical procedures $^{(1)}$. Based on this, and in addition to the video and the open dialogue presentation class, simulation was used as a way to facilitate the learning process and to offer students the opportunity to handle the materials and practice the performance of the procedure.

In the Brazilian context, some universities have used educational models directed at effectively facilitating and qualifying students' learning according to the knowledge demands of the globalized world, and one of these models is tutoring(3).

In the present study, the participation of a tutoring nurse in the intervention group was added to the simulation context and this group presented significantly higher practical performance scores than the group which had only the support of a self-learning tutorial. The tutor acted with the purpose of showing, clarifying and making observations about the steps for the performance of the CVC-SI dressing and assisting with the development of skills related to this procedure, showing an effective and significant professional performance during the learning process.

In that sense, the literature points out that tutors have a central role, as they establish the link between the student and the academic structure. This contribution reinforces their relationship with the student and is most enriching in the learning process. In addition, the role of the tutor in the development of technical and relational skills for the performance of the job is highlighted(3).

The use of simulation added to the tutor assistance enabled the discussion with the student about aspects related to the object of the learning process, making them reflect, for example, about the possible deficiencies they presented during the technical execution, and therefore making the learning process more significant in the students' perception. Feedback is considered an important tool professionals who follow the training process in the simulation laboratory need to use, and their actions should be directed at reinforcing adequate performance, correcting errors and explaining the points where the students need to improve, and this should be done immediately after simulation ${ }^{(14)}$.

Furthermore, concerning the tutor figure, in this study, a nurse played the role of a tutor, who can be considered an experienced professional with knowledge in a specific field, who assists with professional preparation and shares knowledge through education, training, coaching, feedback etc., in order to facilitate students' intellectual and professional development in appropriate environment for knowledge construction and reconstruction ${ }^{(15)}$. 
These characteristics are recognized in the analysis of the tutoring nurse's role in the present research while assisting with the acquisition of skills for the performance of the CVC-SI dressing procedure. This performance can be mainly observed through those items that showed greater discrepancy between the group with the tutor's assistance and the group using the self-learning tutorial, as the tutor was allowed to assist the student to satisfactorily perform the procedure items.

In addition to classroom education, the figure of the tutor has been considered a learning strategy for undergraduate and postgraduate students who undertake semi-attending courses in the health care field, both in information exchange and in the search for assistance to clarify questions about the course contents $^{(16)}$.

As for the evaluation of the learning experience, all participants accepted it well and reported about the importance of the procedure, information that confirms the results of other studies ${ }^{(10,12)}$. On the other hand, the students who used the self-learning tutorial reported they had felt insecure due to the uncertainty of performing the procedure correctly and the impossibility to communicate with the researchers for clarification.

\section{Conclusion}

This study compared the learning process of nursing students using simulation to develop the CVC-SI dressing, associated to an open dialogue presentation class, to a video showing the procedure and to the assistance of a tutoring nurse or of a self-learning tutorial about the technique steps.

The students of both groups had similar right answer rates in relation to the assessment of cognitive knowledge before and after watching the video and the open dialogue presentation class. However, the students who had the assistance of a tutoring nurse to perform the dressing performed better in the practical evaluation in comparison to the group using the self-learning tutorial.

As a result, this study shows that the use of simulation together with the assistance of a tutoring nurse is an effective training strategy for the nursing degree.

It is important to mention that the development of skills and abilities concerning the performance of procedures, as per the CVC-SI dressing, is a challenge at nursing schools, considering that strategies should be constantly updated in order to fulfill the students' demands. As a result, simulation advances in the nursing field are of upmost importance and the tutor figure should be highlighted in the learning process, taking into consideration the role this professional plays in knowledge acquisition and in the development of critical-reflexive thoughts and attitudes.

\section{References}

1. Teixeira INDO, Felix JVC. Simulação como estratégia de ensino em enfermagem: revisão de literatura. Interface - Comunic, Saude, Educ. 2011;15(39):117383.

2. Jeffries PR, McNelis AM, Wheeler CA. Simulation as a vehicle for enhancing collaborative practice models. Crit Care Nurs Clin North Am. 2008;20(4):471-80.

3. Geib LTC, Krahl M, Poletto DS, Silva CB. A tutoria acadêmica no contexto histórico da educação. Rev Bras Enferm. 2007;60(2):217-20.

4. Botti SHO, Rego STA. Docente-clínico: o complexo papel do preceptor na residência médica. Physis. 2011;21(1):65-85.

5. Saupe R, Geib LTC. Programas tutoriais para os cursos de enfermagem. Rev. Latino-Am. Enfermagem. 2002;10(5):721-6.

6. Silveira RCCP, Galvão CM. O cuidado de enfermagem e o cateter de Hickman: a busca de evidências. Acta Paul Enferm. 2005;18(3):276-84.

7. Silveira RCCP, Braga FTMM, Garbin LM, Galvão CM. The use of polyurethane transparent film in indwelling central venous catheter. Rev. Latino-Am. Enfermagem. 2010;18(6):1212-20.

8. Mesiano ERAB, Merchán-Hamann E. Bloodstream infections among patients using central venous catheters in intensive care units. Rev. Latino-Am. Enfermagem. 2007;15(3):453-9.

9. Carvalho EC. Comportamento verbal enfermeiropaciente: função educativa e educação contínua do profissional [tese de doutorado]. Ribeirão Preto (SP): Escola de Enfermagem de Ribeirão Preto da Universidade de São Paulo; 1985. 225 p.

10. Cardoso AF, Moreli L, Braga FTMM, Vasques CI, Santos CB, Carvalho EC. Effect of a video on developing skills in undergraduate nursing students for the management of totally implantable central venous ports. Nurse Educ Today. 2012;32:709-13.

11. Oliveira BM, Mininel VA, Felli VEA. Qualidade de vida de graduandos de enfermagem. Rev Bras Enferm. 2011;64(1):130-5.

12. Lee JC, Boyd R, Stuart P. Randomized controlled trial 
of an instructional DVD for clinical skills teaching. Emerg Med Australas. 2007;19(3):241-5.

13. Willians B, French J, Brown T. Can interprofessional education DVD simulations provide an alternative method for clinical placements in nursing? Nurse Educ Today. 2009;29(6):666-70.

14. Santos MC, Leite MCL. A avaliação da aprendizagem na prática da simulação em enfermagem como feedback de ensino. Rev Gaucha Enferm. 2010;31(3):552- 6.

15. Flores GC, Kury EC, Abreu LF. Tutoría en educación superior: una revision analítica de la literature. Rev Educ Superior. 2011; 1(157):189-209.Spanish.

16. Peixoto HM, Peixoto MM, Alves ED. Estratégias de aprendizagem utilizadas por graduandos e pósgraduandos em disciplinas semipresenciais da área de saúde. Rev. Latino-Am. Enfermagem. 2012;20(3):551-8. 